Библиографија / Bibliography

Срђан Р. Петровић*

Универзитет у Београду

Филолошки факултет

Катедра за славистику
УДК

013:378.245(497.11):[811.161.1"1960/2015"

ДОИ

https://doi.org/10.18485/analiff.2016.28.2.17

\title{
БИБЛИОГРАФИЈА ДОКТОРСКИХ ДИСЕРТАЦИЈА О РУСКОМ ЈЕЗИКУ ОДБРАҢЕНИХ НА ФИЛОЛОШКОМ ФАКУЛТЕТУ УНИВЕРЗИТЕТА У БЕОГРАДУ ОД 1960. ДО 2016. ГОДИНЕ
}

У домаћој науци већ дуго времена постоји интересовање за дисертациона истра-живања из области српске лингвистичке русистике перципирана у библиографском кључу. У том погледу један од репрезентативних примера који на успешан начин негује и у континуитету испољава интересовање за библиографску делатност јесте Катедра за славистику Филолошког факултета Универзитета у Београду (детаљније в. Пипер, 2005). Тако су постојећа сазнања превасходно пласирана путем библиографија општи-јег (славистичког) карактера у оквиру периодичних публикација (нпр. Чудомировић, 1995; Голубовић, 2005), потом, у нешто мањој мери, у оквиру монографских остварења (нпр. Вићентић, Пипер, 2006: 102-105), као и засебних, углавном прегледних чланака.

Овај прилог има за циљ да путем библиографије докторских дисертација одбра-њених на Филолошком факултету Универзитета у Београду закључно са 2015. годином пружи кумулативни преглед интересовања и дисертационих остварења из области науке о руском језику ${ }^{11}$ у датом периоду. Као почетни оквир узета је 1960. година, када је Филолошки факултет постао засебна и самостална високошколска институција.

Докторске дисертације су наведене према хронолошком критеријуму на основу године одбране. Допунски податак унет је у библи-

*\$srdjan09@mail.ru

1 Наука о руском језику поима се у ужем смислу, стога су из библиографије изузете докторске дисерта-ције из области методике наставе руског језика. Њихов преглед и комплетан библиографски опис за пе-риод до 2015. године в. у: Петрович, 2015. 
ографски опис искључиво у случаје-вима када се година одбране разликовала од године наведене на публикацији. У библи-ографију смо уврстили докторске дисертације који у целости или конфронтативно ра-светљавају неко од релевантних подручја науке о руском језику. У циљу достизања ви-шег степена свеобухватности и прегледности након библиографског описа налази се предметни регистар.

Напомињемо да је дат преглед докторских дисертација лица која су стекла нау-чни степен доктора филолошких наука према прописима који су важили до ступања на снагу Закона о високом образовању. Ради употпуњавања података усврстили смо и од-брањене докторске дисертације према новом систему болоњских студија, те ради дифе-ренцирања издвојили помоћу трију звездица (***) уз име кандидата.

1976.

1. МАТИЈАШЕВИЋ, ЈеЛка

Развитак суфикса с елементом - К - у руском језику / Јелка Матијашевић. - 429 листова.

Одбрањена 1977.

1977.

2. СТАНКОВИЋ, Богољуб

Интерференција у предикатским синтагмама руског и српскохрватског језика / Богољуб Д. Станковић. - [2], 261 лист.

1979.

3. МАРОЈЕВИЋ, Радмило

Посесивне категорије у руском језику : у свом историјском развитку и данас / Рад-мило Маројевић. - 530 листова.

Одбрањена 1980.

1982.

4. БРАЈИЧИЋ, Олга

Функција синонимије партиципских конструкција и адномиланих односних рече-ница у руском и српскохрватском књижевном језику / Олга Брајичић. - 526 листо-ва.

Одбрањена 1983. 
БИБЛИОГРАФИЈА ДОКТОРСКИХ ДИСЕРТАЦИЈА О РУСКОМ ЈЕЗИКУ ОДБРАҢЕНИХ НА ФИЛОЛОШКОМ ФАКУЛТЕТУ УНИВЕРЗИТЕТА У БЕОГРАДУ ОД 1960. ДО 2016. Г.

1984.

5. МИЛИНКОВИЋ, Љубо

Датив у савременом руском и српскохрватском језику : конфронтативна анализа / Љубо Милинковић. - 361 лист.

Одбрањена 1985.

1986.

6. ВУКОВИЋ, Борислав

Категорија неодређености у руском и српскохрватском језику / Борислав Вуко-вић. - 312 листа.

1988.

7. РАДИЋ-ДУГОЊИЋ, Милана

Међујезички хомоними и пароними у руском и српскохрватском језику / Милана Радић-Дугоњић. - 265 листова.

1990.

8. СТИјОВИЋ, Светозар

Руски и црквенословенски елементи у језику Његошевих песничких дела / Све-тозар Стијовић. - 296 листова.

Одбрањена 1991.

1991.

9. МУШОВИЋ, Абдулах

Фразеолошкејединице с адвербијалном функцијом у савременом руском и срп-скохрватском језику / Абдулах Х. Мушовић. - 332 листа.

10. ТЕРЗИЋ, Александар

Синтагме са генитивом без предлога у синтаксичким варијантним редовима у ру-ском језику / Александар С. Терзић. - 469 листова.

1992.

11. АЛАБУРИЋ, Јелица

Функција екстралингвистичких знања у информативном превођењу техничких текстова са руског на српскохрватски / Јелица С. Алабурић. - 287 листова.

Одбрањена 1993. 
1993.

12. ТОШИЋ, Борисав

Преводна семантизација у двојезичном рјечнику: на материјалу руског и српско-хрватског језика / Борисав В. Тошић. - 395 листова.

1995.

13. ПОЈАТИЋ, Дурија

Глаголске именице у друштевно-политичкој лексици у руском и српском језику : творбено-семантички типови и синтаксичке функције / Дурија А. Појатић. - 302 листа.

14. СТОЈАНОВИЋ, Андреј

Синтаксичке одлике научног стила руског и српског језика у области технике / Андреј М. Стојановић. - 430 листова.

1996.

15. ЛАИНОВИЋ-СТОЈАНОВИЋ, Надежда

Лингвистичка анализа научног стила руског и српског језика у области електро-технике : лексички ниво / Надежда ЛаиновићСтојановић. - 458 листова.

Одбрањена 1997.

2002.

16. АЈДУКОВИЋ, Јован

Русизми у савременим јужнословенским и западнословенским књижевним језици-ма : према квалификатору у лексикографским изворима / Јован Ајдуковић. - 851 лист.

Одбрањена 2003.

2004.

17. БЕЛОКАПИЋ ШКУНЦА, Вера

Лексичке одлике руског и српског пословног језика / Вера Белокапић-Шкунца. - 283 листа.

Одбрањена 2005.

2007.

18. ПЕЈАНОВИЋ, Ана 
БИБЛИОГРАФИЈА ДОКТОРСКИХ ДИСЕРТАЦИЈА О РУСКОМ ЈЕЗИКУ ОДБРАЮЕНИХ НА ФИЛОЛОШКОМ ФАКУЛТЕТУ УНИВЕРЗИТЕТА У БЕОГРАДУ ОД 1960. ДО 2016. Г.

Фразеологија „Горског вијенца““ и његових руских превода / Ана Пејановић. - 282 листа.

2010.

19. ИЛИЋ, Виолета

Лакуна као лексикографски и преводилачки проблем на плану руског и српског језика / Виолета П. Илић. - 228 листова.

20. МАРИЋ, Биљана

Синтаксичка деривација у савременом руском књижевном језику у поређењу са српским / Биљана Марић. - 445 листова.

21. МАРКОВИЋ, Дејан

Конфронтациона анализа компјутерске лексике у руском језику у поређењу са српским / Дејан С. Марковић. - 320 листова.

22. МАРОЈЕВИЋ, Милена

Предикативне речи у руском језику и њихови српски еквиваленти : морфо-син-таксички, лексикографски, преводилачки аспект / Милена Маројевић. - 315 листо-ва.

2013.

23. ТЕРЗИЋ, Светлана

Изражавање елативности и суперлативности у руском и српском језику / Светлана Терзић. - 483 листа.

Одбрањена 2014.

24. ВУКИЋЕВИЋ, Весна

Категорије вида и времена глагола у руском језику у поређењу са српским : са лингвистичког и преводилачког аспекта / Весна В. Вукићевић. - 209 листова.

2014.

25. ЛЕПОЈЕВИЋ, Јелена Б.

Супстантивизација као творбени процес и именице неименичких деклинација у руском и српском језику / Јелена Б. Лепојевић. - 361 стр.

Одбрањена 2015.

26. МЕДЕНИЦА, Лука ***

Незаменички прилози са просторним значењем у руском и српском језику / Лука Меденица. - 285 стр. 
27. МЛАДЕНОВИЋ, Маја 3.

Граматички статус и синтаксичке функције руских речи естй, ней и ga и њихови српски еквиваленти / Маја 3. Младеновић. -272 стр.

Одбрањена 2015.

\section{ПРЕДМЕТНИ РЕГИСТАР}

\begin{tabular}{|c|c|}
\hline \multicolumn{2}{|l|}{ Савремени руски језик } \\
\hline 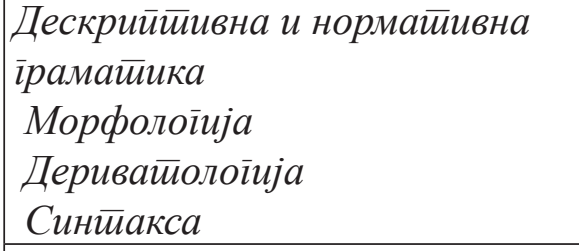 & $\begin{array}{l}22,25,27 \\
1,13,25 \\
2,4,10,13,14,20,22,27\end{array}$ \\
\hline Функционална ірамайика & $3,5,6,23,24$ \\
\hline Лексиколоіија и лексикоїрафија & $7,8,12,13,15,16,17,19,21,22,26$ \\
\hline Фразеолоїија & 9,18 \\
\hline Сйилистиика & $8,14,15,17$ \\
\hline 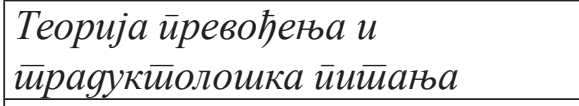 & $11,18,19,22,24$ \\
\hline \multicolumn{2}{|l|}{ Исӣорија рускоі̄ језика } \\
\hline 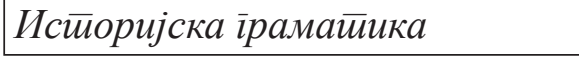 & 1,3 \\
\hline
\end{tabular}

\section{Литература}

Вићентић, Б., Пипер, П. (2006). Библиоірафија срӣске линівисииччке русистиике (1991-2000). Нови Сад: Матица српска (Нови Сад: Прометеј).

Голубовић, А. (2005). Библиографија докторских дисертација о словенским јези-цима и књижевностима одбрањених на Филолошком факултету у Београду од 1995-2004. године, Зборник Майице срӣске за слависиику, 68, 271-276. 
БИБЛИОГРАФИЈА ДОКТОРСКИХ ДИСЕРТАЦИЈА О РУСКОМ ЈЕЗИКУ ОДБРАњЕНИХ НА ФИЛОЛОШКОМ ФАКУЛТЕТУ УНИВЕРЗИТЕТА У БЕОГРАДУ ОД 1960. ДО 2016. Г.

Петрович, С. (2015). Библиография докторских диссертаций по методике пре-подавания русского языка, защищённых на филологическом факультете Белградского университета до 2015 года, Русский язык как инославянский, 7, 249-252.

Пипер, П. (2005). О библиографској делатности Катедре за славистику и Слави-стичког друштва Србије, Слависииика, IX, 425-427.

Чудомировић, Б. (1995). Магистарски радови о словенским језицима и књижев-ностима, одбрањени на Филолошком факултету у Београду у периоду од 1985. до 1994., Зборник Майиие срӣске за славистиику, 48/49, 203-214. 